\title{
Changes in the intestinal bacterial profile and serum biochemical parameters of Nile Catfish Clarias lazera after feeding with probiotic.
}

\author{
Esam H. Rizkalla ${ }^{1}$; Hala, F. Habashi ${ }^{2}$; Ahmed T. Ali $^{3}$
}

1- Biochemistry, Nutritional Deficiency Diseases and Toxicology Dept.

2- Bacteriological Dept.

3- Fish Diseases Dept., Animal Health Res. Inst., Agri. Res. Cen., Dokki, Giza, Egypt.

e-mail: esamrizkalla@hotmail.com

\section{ABSTRACT}

In this study, the experimental set-up was based on fed Clarias lazera commercial diet with probiotic for 45 days either 1 time/week $\left(\mathrm{W}_{1}\right)$ all over the experiment or 3 times/week for the $1^{\text {st }}$ two weeks then 1 time/week till the end of the experiment $\left(\mathrm{W}_{3}\right)$. Bacteriological and biochemical examinations were done on intestinal tract and serum respectively.

Bacteriological investigation revealed the presence of Escherichia coli and Klebsiella spp. in all groups and Pseudomonas aeruginosa failed to be isolated from $\mathrm{W}_{1}$ and $\mathrm{W}_{3}$. Bacterial isolates proved to be pathogenic for mice, positive for Congo red binding activity and toxigenic in infant mice. The intestinal total aerobic bacterial count; Enterobactereacae count and coliform count in males and females of both $\mathrm{W}_{1}$ and $\mathrm{W}_{3}$ fish groups were significantly lower than the respective values in control group. Significant low values were detected in $W_{3}$ group compared to $W_{1}$ group. Significant sex differences in the three counts were detected in the three groups of fish except the Enterobactereacae count in $\mathrm{W}_{3}$ group.

Concentrations of serum ammonia and urea were significantly decreased in both treated groups compared to the control group. Both serum items were significantly lower in $\mathrm{W}_{3}$ group than that in $\mathrm{W}_{1}$ group. Significant sex difference was recorded in serum creatinine of the three groups (females lower than males).

The activities of serum alkaline phosphatase; alanine aminotransferase and aspartate aminotransferase enzymes significantly differed according to sex with a general trend that these enzymes were significantly higher in $\mathrm{W}_{3}$ group than that of $\mathrm{W}_{1}$ group.

Serum total protein, albumin, globulin and $A / G$ ratio in fish of $\mathrm{W}_{1}$ group were more affected by probiotic administration than that in $\mathrm{W}_{3}$ group. These serum protein items in all groups were significantly affected by sex. Serum IgM level in both sexes of $\mathrm{W}_{1}$ group was significantly higher than that in both control and $\mathrm{W}_{3}$ groups.

A correlation analysis was conducted to determine the strength of the association between serum biochemical parameters and viable total bacterial count; Enterobactereacae and coliform counts in the guts of fish. Male fish showed similarity of the correlations analysis between the three bacterial counts and the different serum biochemical parameters, while female fish detected some variations according to the type of bacterial count.

Keywords: Bacterial profile, serum biochemical, Clarias lazera, Probiotics 


\section{INTRODUCTION}

World aquaculture has grown tremendously during the last years becoming an economically important industry (Subasinghe et al., 2009). Today it is the fastest growing food-producing sector in the world with the greatest potential to meet the growing demand for aquatic food (FAO, 2006). Globally, aquaculture is expanding into new directions, intensifying and diversifying (Austin et al., 1995). Application of probiotic for fish aquaculture has shown much potential in recent years (Irianto and Austin, 2002). Benefits across a range of fish species include improved water quality, growth performance, feed utilization, resistance to disease and immunostimulation (Burr et al., 2005; Abdel-Tawwab et al., 2008 and Kamgar et al., 2013). Nikoskelainen et al. (2003) and Panigrahi et al. (2004, 2005) confirmed that dietary supplementation with various indigenous and exogenous useful microorganisms "probiotics" may be an effective biotherapeutic or prophylactic means in aquaculture. In the fish farming industry, disease is a major problem with the increasing intensification and commercialization of aquaculture production (Bondad-Reantaso et al., 2005). The probiotics are considered as a new strategies in feeding and health management in fish aquaculture practice (Denev, 2008).

Probiotic agents exert a beneficial effect via a wide array of actions. These include: immunostimulation and increase resistance to disease (Irianto and Austin, 2002; Nikoskelainen et al., 2003; Panigrahi et al., 2004, 2005; Balcázar et al., 2007); improvements in nutrition and growth performance (Irianto and Austin, 2002; Abd ElRhman et al., 2009). In addition, probiotics improved activity of gastro-intestinal microbiota of fish species (Burr et al. 2005). By the above reasons, the use of microbial probiotics in fish aquaculture is now widely accepted. The exact mode of action of the probiotic bacteria has not been fully elucidated. Very little is known about the relative importance of these mechanisms (Kesarcodi-Watson et al., 2008).

Commercially available probiotics not only include pure strains and defined mixture of specific strains, but also consortia of strains and undefined mixtures (Irianto and Austin, 2002; Balcázar et al., 2007). Probiotics that currently used in aquaculture industry include a wide range of taxa-from Lactobacillus, Bifidobacterium, Pediococcus, Streptococcus and Carnobacterium spp. to Bacillus, Flavobacterium, Cytophaga, Pseudomonas, Alteromonas, Aeromonas, Enterococcus, Nitrosomonas, Nitrobacter, Vibrio spp., yeast (Saccharomyces, Debaryomyces) and etc. (Irianto and Austin, 2002; Burr et al., 2005; Sahu et al., 2008).

The inclusion of non-pathogenic microorganisms in diet could exert beneficial physiological effects beyond the nutritional impact of food. Comprehensive research to more fully characterize the intestinal microbiota of prominent fish species, mechanisms of action of probiotics, and their effects on intestinal ecosystem, fish health and performance is warranted. Also, all probiotics must be evaluated for their safety before being used in fish nutrition. Despite its wider acceptance in aquaculture, many questions remain unanswered about its influence on fish physiology. The present work, focused on the role of certain physiological functions of Nile catfish Clarias lazera as influenced by a probiotic mixture (consists of strains of lactic acid bacteria and yeast cells) supplementation. Concurrent observations were also made on the changes in the composition of the gut flora before and after the probiotic feeding. Measurements of the serum chemical composition have been used as a reliable index to estimate nutritional conditions and gastrointestinal bacterial profile changes. 


\section{MATERIALS AND METHODS}

\section{Fish:}

Clarias lazera (average length $38.5 \pm 3.4$ and $35.2 \pm 3.2 \mathrm{~cm}$ for males and females respectively) were obtained from commercial fisheries in Giza governorate. The health status was examined immediately upon arrival according to the methods described by Austin and Austin (1989). Fish were acclimatized in freshwater glass aquaria $(100 \times 50 \times 50 \mathrm{~cm})$ for 2 weeks, maintained in aerated de-chlorinated tap water and fed commercial diet ( $25 \%$ protein) in a ratio of $3 \%$ body weight. Glass aquaria were sterilized by potassium permanganate $(4 \mathrm{mg} / \mathrm{l})$ according to Post (1987).

\section{Probiotic:}

Avi-Lution ${ }^{\circledR}$ was developed by Agri-King, Inc., Fulton, Illinois, USA. This probiotic contains $21.6 \%$ live yeast cells (Saccharomyces cerevisiae, $5 \mathrm{X} 10^{9} \mathrm{CFU} / \mathrm{g}$ ); $16.8 \%$ Enterococcus faecium bacteria $\left(1 \mathrm{X} 10^{10} \mathrm{CFU} / \mathrm{g}\right) ; 2.5 \%$ rapidly proliferating strain of lactic-acid producing bacteria (Bacillus subtilis, 5X109 CFU/g); $8 \%$ nondigestible oligosaccharides [inulin $(92 \%)$, glucose + fructose + sucrose $(8 \%)$ ]; 27.7 $\%$ yeast culture (corn germ meal, cane molasses and corn syrup); $22.1 \%$ calcium carbonate as carrier and $1.3 \%$ other ingredients [paraffin oil $(1.1 \%)$, sodium silico aluminate $(0.2 \%)$ ] . The recommended Avi-Lution ${ }^{\circledR}$ supplementation rate of $0.05 \%$ contributes about $275 \times 10^{6}$ lactic acid bacteria/Kg of feed (Hooge, 2000). The mixture is available as a granular premix.

\section{Experimental design:}

After the acclimatization period, bloods and excreta of whole intestinal tract were collected from ten fish (initial group). The experimental set-up was based on fed fish commercial diet ( $25 \%$ protein) with probiotic "1 kg/ton ration" (Agri-King, $2000)$ for 45 days either one time/week all over the experiment $\left(\mathrm{W}_{1}\right.$ group) or three times/week for the $1^{\text {st }}$ two weeks then 1 time/week tell the end of experiment $\left(\mathrm{W}_{3}\right.$ group). Each group consists of 5 males and 5 females. The probiotic dose was dispersed into firm gelatinous capsules and pushed into the stomach of the fish. Fish of control group received the same gelatinous capsules free from probiotics.

\section{Sampling:}

Blood samples were withdrawn from caudal vein into Eppendorf tubes without anticoagulant in syringe and allowed to clot at room temperature for $2 \mathrm{~h}$. The tubes were kept slop at $4{ }^{\circ} \mathrm{C}$ for overnight, then centrifuged at $3000 \times \mathrm{g}$ for $10 \mathrm{~min}$ and the supernatant serum was collected. The serum was stored immediately at $-20{ }^{\circ} \mathrm{C}$ until analyses.

After blood sampling, fish were externally washed with sterilized water and 70 $\%$ ethanol before opening the ventral surface to reduce potential contamination with skin bacteria. The whole intestinal tract of each fish was immediately removed aseptically with sterile scalpel and forceps (Soondeuk and Yeonhee, 1995 and Matyar et al., 2004). Each sample was put in sterile labeled plastic bags for bacteriological examination.

\section{Bacteriological examination:}

A loopful of intestinal content of each fish was streaked and cultured on blood agar, MacConkey agar, nutrient agar, Eosin methylene blue agar and pseudomonas agar base. All plates were incubated for $24-48$ hours at $37{ }^{\circ} \mathrm{C}$. The developed colonies were identified morphologically and biochemically according to Carter and Cole (1990). 
- Bacterial count:

The intestinal content of each fish was stripped out with sterile forceps and weighed then placed in a sterile test tube having $1 \%$ peptone water $(\mathrm{pH} 7.0)$ and serial dilutiton was done according to Danish Standards Association (2002).

- Aerobic plate count (ICMSF, 1982): All inoculated plates were incubated at $35^{\circ} \mathrm{C}$ for 24 hours. Plates containing 30 - 300 colonies were used to calculate bacterial population results.

- Enterobactereacae count (ICMSF, 1978):

- Coliform count M.P.N. (ICMSF, 1978 and Peter et al., 1998): Tubes showing acid and gas productions were considered positive. The most probable number was estimated using table De Man.

- Detection of enteropathogenic E. coli (ICMSF, 1978 and Finegold and Martin, 1982):

- Some virulence factors of isolated microorganisms (E. coli, Klebsiella spp. and Pseudomonas spp.): including heamolytic activity (Beutin et al., 1989); congo red binding test (Gray et al., 1990); enterotoxin assay by infant mouse test according to Kirov et al. (1986) and Robins-Brown et al. (1993) as well as pathogenicity test according to Brook et al. (1985) and Palumbo et al. (1989).

\section{Biochemical parameters:}

Serum alkaline phosphatase (ALP, EC. 3.1.3.1) (Rosalki et al., 1993), total proteins (Burtis et al., 1999) and albumin (Doumas et al., 1971) concentrations were measured using Reactivos GPL Kits, Barcelona, España. Aspartate aminotransferase (AST, EC. 2.6.1.1) and alanine aminotransferase (ALT, EC. 2.6.1.2) (Reitman and Frankel, 1957), ammonia (Konitzer and Voigt, 1963), urea (Fawcett and Soctt, 1960) and creatinine (Bartles et al., 1972) concentrations were measured using BioDiagnostic Kits, Egypt. Serum immunoglobulin (IgM) concentrations were analyzed by radioimmunoassay (RIA) method using RIA Kits (Amersham International Ltd., Amersham, U.K.).

\section{Statistical analysis:}

In bacteriological and serum biochemical analysis, the significant differences $(\mathrm{P}$ $<0.05)$ between groups were determined by a one-way analysis of variance (ANOVA). Comparisons of sex were performed with $t$-tests. Correlation coefficients were used to determine the strength of the associations between serum biochemical parameters and intestinal total bacterial count. All statistics were performed using SPSS for Windows version 11.5 (SPSS Inc., Chicago, IL, USA).

\section{RESULTS}

\section{Bacteriological findings:}

Results of bacteriological investigation on Nile catfish (Clarias lazera) revealed the presence of E. coli and Klebsiella spp. in the four groups examined. It was clear that Pseudomonas aeruginosa failed to be isolated from $\mathrm{W}_{1}$ and $\mathrm{W}_{3}$ (Table 1). Studying virulence factors of the isolates revealed that all tested isolates (E. coli, Klebsiella spp. and Pseudomonas spp.) proved to be pathogenic for mice and were positive for Congo red binding activity as well as toxigenic in infant mouse by mean reading reached 0.087 for all tested strains. 
Table 1: Bacterial isolates from different Clarias lazera groups

\begin{tabular}{|c|c|c|c|c|}
\hline \multirow{2}{*}{ Bacterial isolates } & \multirow{2}{*}{ After acclimatization } & \multicolumn{4}{|c|}{ After experiment } \\
\cline { 3 - 5 } & & Control & $\mathbf{W}_{\mathbf{1}}$ & $\mathbf{W}_{\mathbf{3}}$ \\
\hline E. coli & + & + & + & + \\
\hline Klebsiella spp. & + & + & + & + \\
\hline Pseudomonas spp & + & + & - & - \\
\hline
\end{tabular}

Table (2) demonstrated a significant sex difference $(\mathrm{P}<0.05)$ for the mean intestinal total aerobic bacterial count after the acclimatization group $(314.00 \pm 6.0 \mathrm{X}$ $10^{4}$ for males and $4.40 \pm 0.07 \times 10^{4}$ for females).

Table 2: Intestinal total bacterial count (T.B.C.) and some biochemical serum parameters of Clarias lazera after 2 weeks acclimatization period.

\begin{tabular}{|l|rl|rl|}
\hline \multirow{2}{*}{\multicolumn{1}{|c|}{ Parameters }} & \multicolumn{2}{|c|}{ Male } & \multicolumn{2}{c|}{ Female } \\
\cline { 2 - 5 } & Mean & \pm S.E. & Mean & \pm S.E. \\
\hline T.B.C. $\left(\mathrm{X} 10^{4}\right)$ & 314.00 & 6.00 & 4.40 & $0.07^{*}$ \\
\hline Ammonia $(\mu \mathrm{g} / \mathrm{dl})$ & 258.90 & 7.34 & 253.40 & 35.31 \\
\hline Urea $(\mathrm{mg} / \mathrm{dl})$ & 52.93 & 3.58 & 47.61 & 1.46 \\
\hline Creatinine $(\mathrm{mg} / \mathrm{dl})$ & 0.55 & 0.03 & 0.41 & $0.03^{*}$ \\
\hline ALP $(\mathrm{U} / \mathrm{L})$ & 57.34 & 9.41 & 34.03 & $2.14^{*}$ \\
\hline ALT $(\mathrm{U} / \mathrm{ml})$ & 11.50 & 0.67 & 7.88 & $0.50^{*}$ \\
\hline AST $(\mathrm{U} / \mathrm{ml})$ & 55.75 & 1.01 & 82.53 & $3.09^{*}$ \\
\hline Total Protein $(\mathrm{g} / \mathrm{dl})$ & 4.25 & 0.09 & 5.02 & 0.37 \\
\hline Albumin $(\mathrm{g} / \mathrm{dl})$ & 1.67 & 0.08 & 1.88 & 0.08 \\
\hline Globulin $(\mathrm{g} / \mathrm{dl})$ & 2.58 & 0.12 & 3.14 & 0.30 \\
\hline A/G Ratio & 0.66 & 0.06 & 0.62 & 0.04 \\
\hline IgM $(\mathrm{IU} / \mathrm{ml})$ & 11.76 & 1.14 & 4.29 & $0.53^{*}$ \\
\hline
\end{tabular}

Significant values between the two sexes are represented by $*: \mathrm{P}<0.05$. $\mathrm{n}=5 / \mathrm{sex}$

The results of intestinal total aerobic bacterial count; Enterobactereacae count and coliform count of the three groups of Clarias lazera after 45 days as experimental period were illustrated in Table (3). The three counts in males and females of both $\mathrm{W}_{1}$ and $\mathrm{W}_{3}$ fish groups were significantly lower than the respective values in control group. Also significant differences were detected between both groups with lower values in $\mathrm{W}_{3}$ group than $\mathrm{W}_{1}$ group. Significant sex differences in the three counts were detected in the three groups of fish except the Enterobactereacae count in $\mathrm{W}_{3}$ group.

Table 3: Intestinal total aerobic bacterial count (T.B.C.); Enterobactereacae count and coliform count of Clarias lazera fed on probiotic either 1 time/week for 45 days $\left(\mathrm{W}_{1}\right)$ or 3 times/week for 14 days then 1 time/week for the rest of 45 days $\left(\mathrm{W}_{3}\right)$.

\begin{tabular}{|c|c|c|c|c|c|c|c|}
\hline \multirow{2}{*}{ Parameter } & \multirow{2}{*}{ Sex } & \multicolumn{2}{|c|}{ Control } & \multicolumn{2}{|c|}{$\mathrm{W}_{1}$} & \multicolumn{2}{|c|}{$\mathrm{W}_{3}$} \\
\hline & & Mear & \pm S.E. & Mea & \pm S.E. & Mean & \pm S.E. \\
\hline \multirow{2}{*}{$\begin{array}{c}\text { Intestinal } \\
\text { T.B.C. } \\
\left(\mathrm{X} 10^{4}\right)\end{array}$} & Male & \multicolumn{2}{|c|}{$\begin{array}{r}2502.00 \\
\mathrm{~A}\end{array}$} & 185.2 & 0.37 & \multicolumn{2}{|c|}{$a^{9.45}$} \\
\hline & Female & \multicolumn{2}{|c|}{$\begin{array}{r}234.40 \\
\mathrm{~A}\end{array}$} & \multicolumn{2}{|c|}{ 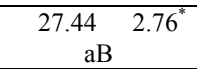 } & \multicolumn{2}{|c|}{$2.11{ }^{0.01^{*}}$} \\
\hline \multirow{2}{*}{$\begin{array}{l}\text { Enterobactereacae count (X } \\
\left.\qquad 10^{4}\right)\end{array}$} & Male & \multicolumn{2}{|c|}{ A } & \multicolumn{2}{|c|}{$\mathrm{aB}$} & $\mathrm{ab}$ & 0.01 \\
\hline & Female & \multicolumn{2}{|c|}{ A } & 0.91 & $0.08^{*}$ & $a b$ & 0.25 \\
\hline \multirow{2}{*}{$\begin{array}{l}\text { coliform count } \\
\quad\left(\mathrm{X} \mathrm{10} 0^{4}\right)\end{array}$} & Male & \multicolumn{2}{|c|}{ A } & 1.08 & 0.01 & $a b$ & 0.005 \\
\hline & Female & \multicolumn{2}{|c|}{ A } & \multicolumn{2}{|c|}{ B } & 0.02 & $0.001^{*}$ \\
\hline
\end{tabular}

Significant values between the two sexes are represented by $*: \mathrm{P}<0.05$.

Small letters $(\mathrm{a} \& \mathrm{~b})$ represent significant values to capital letters (A \& B) respectively by LSD using ANOVA test at $\mathrm{p}<0.05$.

$\mathrm{n}=5 /$ sex/group 


\section{Biochemical findings:}

Table (2) shows the values of serum biochemical parameters of Clarias lazera after 2 weeks acclimatization period. Significant sex differences were detected in which serum creatinine; alkaline phosphatase (ALP); alanine aminotransferase (ALT) and immunoglobulin (IgM) contents were higher in males than females, while serum aspartate aminotransferase (AST) activity was higher in female fish than males.

Tables $(4-6)$ illustrate the results of the control, $\mathrm{W}_{1}$ (fish fed on probiotic 1 time/ week for 45 days) and $\mathrm{W}_{3}$ (fish fed on probiotic 3 times/ week for 14 days then $1 \mathrm{time} /$ week for the rest of the experiment). Concentrations of serum ammonia and urea in both sexes were significantly decreased in both treated groups compared to the control group (Table 4). Serum ammonia values in both sexes of $\mathrm{W}_{3}$ group were significantly lower than that in $\mathrm{W}_{1}$ group. The significant low value of serum urea between $\mathrm{W}_{3}$ and $\mathrm{W}_{1}$ groups was detected only in male fish. For male fish, serum creatinine content was significantly higher in $W_{1}$ group and lower in $W_{3}$ group comparing to control and it was significantly lower in $\mathrm{W}_{3}$ group compared to $\mathrm{W}_{1}$ group (Table 3). Significant sex differences were recorded in serum urea of the control group (female higher than male) and creatinine of the three groups (females lower than males).

Table 4: Serum ammonia, urea and creatinine levels of Clarias lazera fed on probiotic either 1 time/week for 45 days $\left(\mathrm{W}_{1}\right)$ or 3 times/week for 14 days then 1 time/week for the rest of 45 days $\left(\mathrm{W}_{3}\right)$.

\begin{tabular}{|c|c|c|c|c|}
\hline \multirow{2}{*}{ Parameters } & \multirow{2}{*}{ Sex } & Control & $\mathrm{W}_{1}$ & $\mathrm{~W}_{3}$ \\
\hline & & Mean \pm S.E. & Mean \pm S.E. & Mean \pm S.E. \\
\hline \multirow{2}{*}{$\begin{array}{l}\text { Ammonia } \\
(\mu \mathrm{g} / \mathrm{dl})\end{array}$} & Male & $\begin{array}{c}615.60 \\
\mathrm{~A}\end{array}$ & $\begin{array}{c}320.90 \\
\mathrm{aB}\end{array}$ & $\begin{array}{c}179.10 \quad 13.88 \\
\mathrm{ab}\end{array}$ \\
\hline & & $\begin{array}{c}584.40 \quad 26.11 \\
\mathrm{~A}\end{array}$ & $\begin{array}{c}313.20 \\
\mathrm{aB}\end{array}$ & $\begin{array}{c}159.20 \quad 8.48 \\
\mathrm{ab}\end{array}$ \\
\hline \multirow{2}{*}{$\begin{array}{l}\text { Urea } \\
(\mathrm{mg} / \mathrm{dl})\end{array}$} & Male & $\begin{array}{c}38.12 \text { A } \\
\text { A }\end{array}$ & $\begin{array}{c}9.42 \quad 0.04 \\
\mathrm{aB}\end{array}$ & $\begin{array}{c}7.01 \quad 0.58 \\
a b\end{array}$ \\
\hline & & $\begin{array}{c}54.45 \\
\mathrm{~A}\end{array}$ & $\begin{array}{cc}8.51 & 0.48 \\
\mathrm{a} & \end{array}$ & $\begin{array}{cc}7.73 & 0.24 \\
\mathrm{a} & \end{array}$ \\
\hline \multirow{2}{*}{$\begin{array}{l}\text { Creatinine } \\
(\mathrm{mg} / \mathrm{dl})\end{array}$} & Male & $\begin{array}{c}0.76 \\
\mathrm{~A}\end{array}$ & $\begin{array}{c}1.01 \\
\mathrm{aB}\end{array}$ & $\begin{array}{c}0.71 \quad 0.01 \\
a b\end{array}$ \\
\hline & Female & $0.640 .02^{*}$ & $0.65 \quad 0.07^{*}$ & $0.610 .03^{*}$ \\
\hline
\end{tabular}

Significant values between the two sexes are represented by *: $\mathrm{P}<0.05$.

Small letters $(\mathrm{a} \& \mathrm{~b})$ represent significant values to capital letters (A \& B) respectively by LSD using ANOVA test at $\mathrm{p}<0.05$.

$\mathrm{n}=5 /$ sex/group

Table (5) reveals that serum ALP enzyme activities were significantly lower in male fish and higher in female fish of groups $\mathrm{W}_{1}$ and $\mathrm{W}_{3}$ compared to control group. ALP activity in males of $\mathrm{W}_{3}$ group was significantly higher than that of $\mathrm{W}_{1}$ group. ALP activities in female fish were significantly lower and higher than males of control and $W_{1}$ groups respectively. Serum ALT activities in male fish were significantly lower and higher in $\mathrm{W}_{1}$ and $\mathrm{W}_{3}$ groups respectively compared to control group. Serum ALT activities in both sexes of $\mathrm{W}_{3}$ group were significantly higher than that of $\mathrm{W}_{1}$ group. Female fish of $\mathrm{W}_{3}$ group showed significant lower value than that of males (table 5). AST enzyme activities were significantly lower in both sexes of both treated groups compared to control group. AST value in male fish of $\mathrm{W}_{3}$ group was significantly higher than that in $\mathrm{W}_{1}$ group. Sex difference in AST activity was detected only in $\mathrm{W}_{1}$ group where its value in female fish was significantly higher than that in male fish (Table 5). 
Table 5: Serum enzyme activities of Clarias lazera fed on probiotic either 1 time/week for 45 days $\left(\mathrm{W}_{1}\right)$ or 3 times/week for 14 days then 1 time/week for the rest of 45 days $\left(\mathrm{W}_{3}\right)$.

\begin{tabular}{|c|c|c|c|c|}
\hline \multirow{2}{*}{ Parameters } & \multirow{2}{*}{ Sex } & Control & $\mathrm{W}_{1}$ & $\mathrm{~W}_{3}$ \\
\hline & & Mean \pm S.E. & Mean \pm S.E. & Mean \pm S.E. \\
\hline \multirow{2}{*}{$\begin{array}{l}\text { ALP } \\
(\mathrm{U} / \mathrm{L})\end{array}$} & Male & $\begin{array}{c}40.72 \\
\mathrm{~A}\end{array}$ & $24.22{ }_{\mathrm{aB}}^{0.45}$ & 29.33 ab 1.60 \\
\hline & Female & $\frac{22.37}{\mathrm{~A}}{ }^{3.67^{*}}$ & $43.83 \mathrm{a}^{2.46^{*}}$ & $40.98{ }_{a} 6.65$ \\
\hline \multirow{2}{*}{$\begin{array}{l}\text { ALT } \\
(\mathrm{U} / \mathrm{ml})\end{array}$} & Male & $\begin{array}{c}9.02 \\
\mathrm{~A}\end{array}$ & $\begin{array}{c}7.16 \quad 0.04 \\
\mathrm{aB}\end{array}$ & $\begin{array}{c}11.90 \quad 0.82 \\
\underline{a b}\end{array}$ \\
\hline & Female & $\begin{array}{ll}7.84 & 0.48\end{array}$ & $6.05{ }^{1.08}$ & $8.84{ }_{b} 0.91^{*}$ \\
\hline \multirow{2}{*}{$\begin{array}{l}\text { AST } \\
(\mathrm{U} / \mathrm{ml})\end{array}$} & Male & $\begin{array}{c}44.86 \\
\mathrm{~A}\end{array}$ & $\begin{array}{c}22.06 \quad 0.46 \\
\mathrm{aB}\end{array}$ & $\begin{array}{c}37.68 \quad 2.79 \\
\mathrm{ab}\end{array}$ \\
\hline & Female & $\begin{array}{c}43.51 \\
\mathrm{~A}\end{array}$ & $\begin{array}{c}36.55{ }^{0.38^{*}} \\
\mathrm{a}\end{array}$ & $\begin{array}{c}36.80 \\
\mathrm{a}\end{array}$ \\
\hline
\end{tabular}

Significant values between the two sexes are represented by *: $\mathrm{P}<0.05$.

Small letters $(\mathrm{a} \& \mathrm{~b})$ represent significant values to capital letters (A \& B) respectively by LSD using ANOVA test at $\mathrm{p}<0.05$.

$\mathrm{n}=5 /$ sex/group.

Table (6) demonstrated that serum protein levels in fish of $\mathrm{W}_{1}$ group were more affected by probiotic administration than that in $\mathrm{W}_{3}$ group. Serum total protein, albumin, globulin and $\mathrm{A} / \mathrm{G}$ ratio in males of $\mathrm{W}_{1}$ group were significantly lower than that in control group, whereas it were significantly higher in females except $\mathrm{A} / \mathrm{G}$ ratio. In $W_{3}$ group, the significant lower values were observed only in albumin and $A / G$ ratio of males compared to both control and $\mathrm{W}_{1}$ groups.

Table 6: Serum proteins levels of Clarias lazera fed on probiotic either 1 time/week for 45 days $\left(\mathrm{W}_{1}\right)$ or 3 times/week for 14 days then 1 time/week for the rest of 45 days $\left(\mathrm{W}_{3}\right)$.

\begin{tabular}{|c|c|c|c|c|}
\hline \multirow{2}{*}{ Parameters } & \multirow{2}{*}{ Sex } & Control & $\mathrm{W}_{1}$ & $\mathrm{~W}_{3}$ \\
\hline & & Mean \pm S.E. & Mean \pm S.E. & Mean \pm S.E. \\
\hline \multirow{2}{*}{$\begin{array}{l}\text { Total Protein } \\
(\mathrm{g} / \mathrm{dl})\end{array}$} & & $\begin{array}{c}3.89 \\
\mathrm{~A}\end{array}$ & $\begin{array}{c}3.41 \\
\mathrm{a}\end{array}$ & $3.32 \quad 0.27$ \\
\hline & Female & $\mathrm{A}^{3.45}$ & $\begin{array}{c}4.67 \mathrm{a} \\
\mathrm{a}\end{array}$ & 0.23 \\
\hline \multirow{2}{*}{$\begin{array}{l}\text { Albumin } \\
(\mathrm{g} / \mathrm{dl})\end{array}$} & Male & $\begin{array}{c}1.32{ }^{0} \\
\mathrm{~A}\end{array}$ & $\begin{array}{c}0.98 \quad 0.01 \\
\mathrm{aB}\end{array}$ & $\begin{array}{c}0.790 .09 \\
\underline{a b}\end{array}$ \\
\hline & Female & $\begin{array}{c}1.14 \\
\mathrm{~A}\end{array}$ & $\begin{array}{c}1.57 \\
\mathrm{~A}\end{array}$ & $1.22-0.04^{*}$ \\
\hline \multirow{2}{*}{$\begin{array}{l}\text { Globulin } \\
\text { (g/dl) }\end{array}$} & Male & $\begin{array}{c}2.57 \\
\mathrm{~A}\end{array}$ & $\begin{array}{c}2.43 \\
\mathrm{~A}\end{array}$ & $\begin{array}{ll}2.53 & 0.21\end{array}$ \\
\hline & & $\begin{array}{c}2.31 \\
\mathrm{~A}\end{array}$ & $\begin{array}{c}3.10 \\
\mathrm{~A}\end{array}$ & 2.74 \\
\hline \multirow{2}{*}{$\begin{array}{l}\mathrm{A} / \mathrm{G} \\
\text { Ratio }\end{array}$} & Male & $\mathrm{A}^{0.51}$ & $\begin{array}{c}0.40 \\
\mathrm{aB}\end{array}$ & $\begin{array}{c}0.31{ }^{0.03} \\
\end{array}$ \\
\hline & Female & $0.50 \quad 0.03$ & $0.51 \quad 0.04^{*}$ & $0.45 \quad 0.03^{*}$ \\
\hline \multirow{2}{*}{$\begin{array}{l}\mathrm{IgM} \\
(\mathrm{IU} / \mathrm{ml})\end{array}$} & Male & $\begin{array}{c}7.00 \quad 0.19 \\
\mathrm{~A}\end{array}$ & $\begin{array}{c}13.94 \\
\mathrm{aB}\end{array}$ & $\begin{array}{c}6.933_{\underline{b}} \\
0.89\end{array}$ \\
\hline & Female & $\mathrm{A}^{4.37} \mathrm{~A}^{0.21^{*}}$ & $\begin{array}{c}14.00 \quad 2.56 \\
\mathrm{a}\end{array}$ & $\begin{array}{c}11.72{ }^{-} \\
\mathrm{a}\end{array}$ \\
\hline
\end{tabular}

Significant values between the two sexes are represented by $*: \mathrm{P}<0.05$.

Small letters $(\mathrm{a} \& \mathrm{~b})$ represent significant values to capital letters (A \& B) respectively by LSD using ANOVA test at $\mathrm{p}<0.05$.

$\mathrm{n}=5 /$ sex/group 
In female fish, serum IgM levels were significantly higher in $\mathrm{W}_{1}$ and $\mathrm{W}_{3}$ groups than control. Female fish had significantly lower and higher IgM values than male fish in control and $\mathrm{W}_{3}$ groups respectively.

Female fish in the $\mathrm{W}_{1}$ group had significantly higher values of the four parameters than males, while albumin and $\mathrm{A} / \mathrm{G}$ ratio were significantly higher in females of $\mathrm{W}_{3}$ group than males. Serum $\operatorname{IgM}$ level in males of $\mathrm{W}_{1}$ group was significantly higher than that in both control and $\mathrm{W}_{3}$ groups.

A correlation analysis was conducted to determine the strength of the association between serum biochemical parameters and viable total bacterial count; Enterobactereacae count and coliform count in the guts of fish (Table 7). The correlations between serum ammonia, urea and AST and TBC in the guts of both $\mathrm{W}_{1}$ and $\mathrm{W}_{3}$ fish-supplemented with probiotic revealed significant $(\mathrm{P}<0.01)$ positive correlations in both sexes. Significant positive and negative correlations were recorded between serum ALP $(\mathrm{P}<0.01)$ and total protein $(\mathrm{P}<0.05)$ in one side and the TBC in the intestine - on the other side - of both male and female fish respectively.

Table 7: Correlations between intestinal total bacterial count; Enterobactereacae count and coliform count and different serum biochemical items of Clarias lazera.

\begin{tabular}{|c|c|c|c|c|c|c|c|c|c|c|c|c|}
\hline \multirow{3}{*}{ Parameters } & \multicolumn{4}{|c|}{$\begin{array}{l}\text { Intestinal total bacterial count } \\
\text { (T.B.C.) }\end{array}$} & \multicolumn{4}{|c|}{ Enterobactereacae count } & \multicolumn{4}{|c|}{ coliform count } \\
\hline & \multicolumn{2}{|c|}{ Male } & \multicolumn{2}{|c|}{ Female } & \multicolumn{2}{|c|}{ Male } & \multicolumn{2}{|c|}{ Female } & \multicolumn{2}{|c|}{ Male } & \multicolumn{2}{|c|}{ Female } \\
\hline & $\mathrm{r}=$ & $\mathrm{P}<$ & $\mathrm{r}=$ & $\mathrm{P}<$ & $\mathrm{r}=$ & $\mathrm{P}<$ & $\mathrm{r}=$ & $\mathrm{P}<$ & $\mathrm{r}=$ & $\mathrm{P}<$ & $\mathrm{r}=$ & $\mathrm{P}<$ \\
\hline Ammonia & 0.961 & 0.01 & 0.936 & 0.01 & 0.964 & 0.01 & 0.572 & 0.05 & 0.966 & 0.01 & 0.673 & 0.01 \\
\hline Urea & 0.998 & 0.01 & 0.965 & 0.01 & 0.998 & 0.01 & 0.574 & 0.05 & 0.878 & 0.01 & 0.603 & 0.05 \\
\hline Creatinine & -0.265 & N.S. & 0.103 & N.S. & -0.257 & N.S. & 0.229 & N.S. & 0.180 & N.S. & 0.234 & N.S. \\
\hline ALP & 0.895 & 0.01 & -0.704 & 0.01 & 0.892 & 0.01 & -0.492 & N.S. & 0.616 & 0.05 & -0.481 & N.S. \\
\hline ALT & -0.333 & N.S. & -0.004 & N.S. & -0.328 & N.S. & -0.145 & N.S. & 0.025 & N.S. & -0.257 & N.S. \\
\hline AST & 0.660 & 0.01 & 0.788 & 0.01 & 0.654 & 0.01 & 0.455 & N.S. & 0.252 & N.S. & 0.470 & N.S. \\
\hline Total Protein & 0.618 & 0.05 & -0.556 & 0.05 & 0.618 & 0.05 & -0.572 & 0.05 & 0.566 & 0.05 & -0.472 & N.S. \\
\hline Albumin & 0.849 & 0.01 & -0.479 & N.S. & 0.851 & 0.01 & -0.578 & 0.05 & 0.872 & 0.01 & -0.422 & N.S. \\
\hline Globulin & 0.155 & N.S. & -0.545 & 0.05 & 0.153 & N.S. & -0.524 & 0.05 & 0.049 & N.S. & -0.456 & N.S. \\
\hline A/G Ratio & 0.823 & 0.01 & 0.160 & N.S. & 0.826 & 0.01 & -0.069 & N.S. & 0.893 & 0.01 & 0.038 & N.S. \\
\hline IgM & -0.412 & N.S. & -0.711 & 0.01 & -0.405 & N.S. & -0.465 & N.S. & 0.045 & N.S. & -0.446 & N.S. \\
\hline
\end{tabular}

N.S.: Not significant

Serum albumin and $\mathrm{A} / \mathrm{G}$ ratio showed significant $(\mathrm{P}<0.01)$ positive correlations with TBC in the intestine of males, while serum globulin $(\mathrm{P}<0.05)$ and $\operatorname{IgM}(\mathrm{P}<0.01)$ showed significant negative correlations in females. The correlation analysis between Enterobactereacae count and different serum biochemical parameters in male fish detected the same correlations recorded with TBC, while female fish detected significant $(\mathrm{P}<0.05)$ positive correlations with serum ammonia and urea and negative correlation with serum albumin (table 7). Contrary to TBC, serum ALP, AST and IgM showed insignificant correlations with Enterobactereacae count. Also, the correlation analysis between Coliform count and different serum biochemical parameters in male fish detected the same correlations recorded with TBC except that serum ALP and AST showed significant $(\mathrm{P}<0.05)$ positive and insignificant correlations respectively (table 7). In female fish, significant positive correlations were recorded with serum ammonia $(\mathrm{P}<0.01)$ and urea $(\mathrm{P}<0.05)$ whiles the rest of serum parameters did not show any significant correlations. 


\section{DISCUSSION}

The alimentary tract of fish represents an interface between the external environment and the body. It's a complex ecosystem, containing large number of microorganisms and has an important influence on health and disease. The intestine is a complex multifunctional organ. In addition to digesting and absorbing feedstuff, it is critical for water and electrolyte balance, endocrine regulation of digestion, metabolism and immunity (Denev et al., 2009). Microbial populations in the intestinal contents are much higher than those in the surrounding water; this indicates that the intestine provides favorable ecological niches for microorganisms. In addition, some normal bacterial microflora in water such as Pseudomonas spp. can be found in the intestinal tract of fish under normal conditions but may be under environmental stress produce disease (Al-Harbi and Uddin, 2003).

It is revealed isolation of E. coli and Klebsiella spp. from all studied fish groups. However, Pseudomonas spp. was isolated only from acclimatization and control groups (table 1). Examination of acclimatization group showed $314.00 \pm 6 \times 10^{4}$ in male and $4.40 \pm 0.07 \times 10^{4}$ in female (Table 2). The total aerobic count, Enterobacteriacaea count and coliform count of control group were: $2502 \pm 1.3 \times 10^{4}$ $\left(\delta^{\lambda}\right)$ and $234.4 \pm 9.87 \times 10^{4}(q) ; 35.40 \pm 0.05 \times 10^{4}\left(\delta^{\top}\right)$ and $13.95 \pm 5.82 \times 10^{4}$ (ㅇ) and $1.97 \pm 0.005 \times 10^{4}(\overbrace{}^{7})$ and $0.90 \pm 0.28 \times 10^{4}($ ( $)$ respectively (table 3 ). Several studies have demonstrated many bacteria spp. encountered in intestine of different fish. It is generally accepted that the gastrointestinal tract of fish is an important route of infection (Birkbeck and Ringø, 2005). The present results are agreement with Cahill (1990) who isolated E. coli, Klebsiella spp. and Pseudomonas spp. from intestinal tract of fish. Also Soondeuk and Yeonhee (1995) proved that gram negative bacteria constituted $85 \%$ of total isolates among these is Pseudomonas spp. Emikpe et al. (2011) recorded heavy contaminated Clarias gariepinus with high incidences of total aerobic count and Enterobacteriacaea count isolated from their stomach. In addition, Sanaa and Yagoub (2009) isolated Enterrobacteriaecae from intestinal content of fish and verified that the most dominant isolates were E. coli, Klebsiella spp. and Pseudomonas spp. Isolation of Enterobacteriacaea indicated public health hazards and concerns particularly isolation of some highly pathogenic agents as $E$. coli which are not usually associated with normal intestinal flora of fish and potential pathogenic organisms as Klebsiella spp. Moreover, isolation of Pseudomonas spp. is of highly importance because this bacterium plays a considerable role as potential pathogenic bacteria for human and as indicator of food quality as spoilage organism.

Bacteria attached to epithelial surfaces have been demonstrated in the gut of a variety of fresh- and saltwater fish species, and it has been suggested that this attachment is an important factor in determining whether a particular organisms colonizes in the intestinal tract (Ringø et al., 2003).

The effect of probiotic was studied on $\mathrm{W}_{1}$ and $\mathrm{W}_{3}$ groups, in addition control group was used to clarify the effect of probiotic after and before fed on it (table 3). Examination of group $\mathrm{W}_{1}$ revealed that total aerobic count, Enterobacteriacaea count and coliform count were: $185.2 \pm 0.37 \times 10^{4}\left({ }^{\AA}\right)$ and $27.44 \pm 2.76 \times 10^{4}$ ( ( ) $), 2.96 \pm$

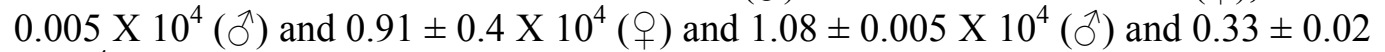
$\mathrm{X} 10^{4}$ (q) respectively. It is clear that fish fed on probiotic one time a week for 45 days showed lower bacterial count than those of control group. So probiotic affect positively the bacterial count either total aerobic count or Enterobacteraecaea count or even coliform count. Regarding to the second group $\left(\mathrm{W}_{3}\right)$, the total aerobic count, Enterobacteriacaea count and coliform count were $9.45 \pm 0.11 \times 10^{4}(\overbrace{}^{\top})$ and $2.11 \pm$ 
$0.01 \times 10^{4}(q), 0.15 \pm 0.006 \times 10^{4}\left(\sigma^{\Uparrow}\right)$ and $0.30 \pm 0.11 \times 10^{4}(q)$ and $0.05 \pm 0.002 \mathrm{X}$ $10^{4}\left({ }^{\pi}\right)$ and $0.02 \pm 0.003 \times 10^{4}($ ( $)$ respectively. This group showed the least bacterial count as they fed on probiotic 3 times per a week for 14 days and then one time per a week for the other 45 days.

Many studies confirmed our results as probiotics currently used as feed additives of fish (Irianto and Austin, 2002 and Sahu et al., 2008). Using Bacillus subtilis as food additives stimulate the gut immune system enhance immune and health status (Mesalhy et al, 2008). In addition adding Enterococcus faecium in food's fish increase growth performance and improve immune response (Wang et al., 2008), also they enhance the digestive enzymes activities in the gut. Moreover, using Saccharomyces cerevisiae in fish food inhibit potential harmful bacteria, stimulate beneficial bacteria and enhance the non specific immunity (He et al., 2009). Tovar et al. (2004) found that live yeast cell have a better growth and feed efficiency. In general, the uses of those potential probiotic stimulate the growth of preferred microorganisms that out compete potentially harmful bacteria and reinforce the organism's natural defense mechanisms. It also increases the digestive enzyme activities and enhances the growth of fish (Shunpei et al., 2009).

In this study all isolates (E. coli, Klebsiella and Pseudomonas) were tested for virulence (the ability to produce haemolysis, to bind with simple dyes and production of enterotoxin in suckling mouse and pathogenicity to mice). The Congo red is a simple dye that can be incorporated into agar media and uptake of dye has been proved to be a virulence marker for several pathogenic bacteria (Statner and George, 1987). All isolates throughout this study gave Congo red positive with different degree in red colour. The detection of enterotoxins in isolates was considered as an indicator of enteropathogenicity. Experimental infection of the mice lead to death of infected mice and the death occurred within 1 - 4 days with mean reading reached 0.087 for all tested strains.

Probiotic agents exert a beneficial effect via a wide array of actions. These include competition for adhesion sites and resistance to colonization; competition for essential nutrients; production of antagonistic compounds against pathogens; enhancement of the immune response and diseases resistance. In addition, probiotics improving enzyme activity for feed digestibility and utilization, fish health and performance (Verschuere et al., 2000 and Wang et al., 2008). Adhesion to the intestinal mucosa has been suggested to enhance the ability to stimulate the immune system (Nikoskelainen et al., 2003). Adhesion of some pathogens to intestinal mucus of fish was significantly reduced by probiotics.

Ammonia is a major nitrogenous metabolic waste produced continuously in the animals. It becomes highly toxic if allowed to accumulate in vivo even to a very low concentration. It is either excreted out or converted to urea via ornithine-urea (o-u) cycle present in their liver (Cohen, 1976). Most freshwater teleosts lacked a complete and functional o-u cycle and were incapable of effective ureogenesis from ammonia (Wilson, 1973). Two siluroid species of freshwater air-breathing teleosts, Hetropneustes fossilis and Clarias batrachus, which are primarily ammoniotelic in their aquatic habitat (Saha et al., 1988), have a complete o-u cycle in their liver and kidney (Saha and Ratha, 1989). When both sexes of C. lazera in the present work were fed either $\mathrm{W}_{1}$ or $\mathrm{W}_{3}$ by the probiotic, both serum ammonia and urea were significantly decreased compared to the control (Table 4) and significant positive correlations were existed between the concentrations of both parameters and the intestinal total aerobic bacterial count; Enterobactereacae count and coliform count (table 7). These results may indicate the decrease of protein catabolism in fish and no 
stress indices due to the action of the probiotic feeding. Working on the water for the same fish species, Abonorag et al. (2011) added probiotic consists of mixture of two strains of lactic acid bacteria "Pediococcus acidilactis, P. pentosaceus" and Bacillus amylolique faciens in addition to two strains of yeast cells "Pichia farinose and Dekera anomala". Comparison of the present results (Table 4) with Abonorag et al. (2011) work showed that the present results of serum ammonia and urea are significantly decreased by probiotic feeding, while probiotic addition in fish water significantly increased both serum parameters. No sex differences were observed in both ammonia and urea values in probiotic fed groups, while Abonorag et al. (2011) detected significant sex difference in serum ammonia of fish exposed to probiotic in water.

Enzymatic activity is mainly dependent on the transport mechanism in the liver, kidney and intestinal mucosa (Vasudevan and Sreekumari, 1998). The assessment of multiple enzymes is considered a valuable tool for indications of tissue damage, which can complement microbiological and histopathological techniques (Racicot et al., 1975). Very little information is available regarding serum enzymes in fish fed probiotics. According to the sex of fish, serum alkaline phosphatase (ALP) activity changed differently in the present work after feeding probiotic. In both fed-groups significant lower and higher values were recorded in the male and female fishes respectively than its respective control groups (table 5) and the significant difference of ALP values between $\mathrm{W}_{1}$ and $\mathrm{W}_{3}$ fed-groups was observed in male fish only. On the same fish species, Abonorag et al. (2011) observed significant higher values of serum ALP were observed in both sexes of fish exposed to probiotic in water and significant sex difference was agreement with the present work. References on different fish species demonstrated a variety of changes in serum ALP due to probiotic feeding. Hoseinifar et al. (2011) found that serum ALP levels were not affected by dietary prebiotic oligofructose. Also, Kumar et al. (2006) reported no significant change in serum ALP activity during feeding Indian major carp (Labeo rohita) with Bacillus subtilis as probiotic and the decreased ALP activity in the B. subtilis fed groups attributed to the effect of $B$. subtilis on the immune system, which conferred sufficient protection to the vital organs of fish. Khattab et al. (2004) showed significant decrease in plasma ALP of Nile tilapia (Oreochromis niloticus) with increasing probiotic levels in the diet. On the other hand, Panigrahi et al. (2010) observed that the viable freezedried probiotic Lactobacillus rhamnosus significantly elevated plasma ALP activity in rainbow trout after feeding for 20 and 30 days. They attributed this elevation to the up-regulation of this enzyme resulting from the increased availability of certain minerals or their retention. Highly significant $(\mathrm{P}<0.01)$ positive and negative correlations between the intestinal total aerobic bacterial count and serum concentration of ALP were demonstrated in both male and female fishes respectively (table 7). The significant positive correlations were also detected with both Enterobactereacae count and coliform count in male fish only.

Values of serum alanine aminotransferase (ALT) were significantly lower and higher in male C. lazera fed W1 and W3 respectively compared to control, while in female fish both treatments did not indicate significant values (table 5). On the other hand, serum aspartate aminotransferase (AST) in both sexes showed significant lower values than controls in the two feeding groups. Abonorag et al. (2011) mentioned that no serious changes occurred in the serum ALT and AST after exposing C. lazera to the probiotic in water. Khattab et al. (2007) recorded significant decrease in plasma AST and ALT in Oreochromis niloticus fed with diet containing mixture of Micrococcus luteus and Pseudomonas species as probiotic. Also, Palikova et al. 
(2004) and Abd El-Rhman et al. (2009) reported the same observation in Cyprinus carpio and $O$. niloticus fed diet containing extract of Cyanobacteria and Pseudomonas species respectively as probiotics. Mahmoud (2012) mentioned that the highest values of plasma AST and ALT were observed in O. niloticus fed on a diet supplemented with yeast (Saccharomyces cerevisiae), while the lowest value of AST was recorded in fish group fed on a diet supplemented with Bifidobacterium bifiduim. The increase in the activities of serum AST and ALT during feeding Indian major carp (Labeo rohita) with Bacillus subtilis as probiotic was reported by Kumar et al. (2006). In the present work, serum AST in both sexes were obviously $(\mathrm{P}<0.01,+$ ve $)$ affected by the intestinal total aerobic bacterial count and by the Enterobactereacae count in male fish only (table 7).

Sex of fish plays an important role in the changes of serum total protein, albumin, globulin and albumin:globulin ratio of $C$. lazera after feeding with the present probiotic. Males of $\mathrm{W}_{1}$ feeding group showed significant lower values of these serum items than the control ones, contrary to that females showed significant higher values (table 6). Serum total protein level is measurable humoral component of the non-specific defense mechanism, and the elevated levels of the total serum protein and globulin indicates that fish are immunologically strong (Nayak et al., 2004). Very low levels of serum total protein have significance in relation to infectious disease, kidney damage and nutritional imbalance in fish (Wedemeyer and McLeay 1981). Wang et al. (2008) indicated no remarkable difference in the total serum protein, albumin content, globulin concentration and $\mathrm{A} / \mathrm{G}$ ratio between the Enterococcus faecium fed tilapia and the control fish. Kumar et al. (2006) described an increase in the serum protein and globulin levels in the Bacillus subtilis feeding major carp and thought to be associated with a stronger innate response in fish and the decrease in the $\mathrm{A} / \mathrm{G}$ ratio is indicative of better immunity of the animal. Khattab et al. (2007) mentioned that the plasma total protein was significantly decreased in Oreochromis niloticus fed with diet containing mixture of Micrococcus luteus and Pseudomonas species as probiotic. Mahmoud (2012) mentioned that the highest value of plasma albumin was recorded in fish fed on a diet supplemented with Lactobacillus acidophilus, while the highest value of globulin was achieved with fish group fed on a diet supplemented with bacterial mixture (Lactobacillus acidophilus, Streptococcus thermophilus and Bifidobacterium bifiduim) and yeast (Saccharomyces cerevisiae). On the other hand, the lowest values of total protein and albumin were recorded in fish group fed on a diet supplemented with Bifidobacterium bifiduim. The results of Bandyopadhyay and Das Mohapatra (2009) supported the use of probiotic (Bacillus circulans) to be an important immunostimulant in Catla catla. They concluded that the lowest significant $\mathrm{A} / \mathrm{G}$ ratio observed in sera of fish fed $B$. circulans might be due to increased lymphocyte proliferation and subsequent immunoglobulin production.

IgM is an important immunoglobulin class. It is the first immunoglobulin to appear in evolution and commonly the only immunoglobulin class described in fish (Magnadóttir, 1998). The concentration of IgM in serum from several fish species has been surveyed (Israelsson et al., 1991) and the results obtained by Magnadóttir (1998) fall within the range reported $\left(0.7-17 \mathrm{mg} \mathrm{ml}^{-1}\right)$. Several studies have also demonstrated considerable individual variations in serum IgM levels amongst fish. This may be related to size/age (Klesius, 1990; Magnadóttir et al., 1999b), the environmental conditions (Olesen and Vestergard-Jørgensen, 1986; Klesius, 1990; Magnadóttir et al., 1999a) or the disease status (Magnadóttir et al., 1995). Our study indicated that probiotic feeding significantly raised serum IgM in both sexes of $C$. lazera fed either $\mathrm{W}_{1}$ or $\mathrm{W}_{3}$ (table 6). The probiotic effect on serum IgM was more 
obviously in $\mathrm{W}_{1}$ group. In fish little has been done in terms of studying, how the immune system is affected upon probiotic stimulation. Working on rainbow trout (Oncorhynchus mykiss), both Panigrahi et al. (2004) and Kamgar et al. (2013) found that IgM rate was increased in the Lactobacillus rhamnosus- and Bacillus subtilis-fed fish respectively. Panigrahi et al. (2005) reported that the plasma total Ig level of all the probiotic fed rainbow trout groups irrespective of the form of lactic acid bacteria (LAB) showed an increasing trend at 20 days. Thereafter, the level of total immunoglobulin decreased in all LAB fed groups reaching levels similar to that in control group of fish at 30 days suggesting that the stimulation of the immune system was a short-term phenomenon attributable to the probiotic. Upon withdrawal of the probiotic diets, the LAB disappeared from the intestine and the elevated immune parameters returned to the prefed level. It has been demonstrated that viable LAB are more efficient at enhancing certain aspects of immune function than the non-viable heat-killed form. The heightened immune response observed by Panigrahi et al. (2004; 2005) can be concluded that the probiotic L. rhamnosus elicits the fundamental non specific immune parameters like phagocytosis, lysozyme and serum alternate complement activities in rainbow trout. Besides, the gut colonization is influenced by the level and duration of feeding. The results of Nikoskelainen et al. (2003) and Tukmechi et al. (2007) showed that the total plasma immunoglobulin level was increased significantly in rainbow trout (O. mykiss) that supplemented the Lactobacillus rhamnosus in the diet. The ability of Lactococcus lactis, Lactobacillus sakei and Leuconostoc mesenteroides to modify the intestinal microbiota and stimulate the plasma total immunoglobulin level in brown trout (Salmo trutta) was elucidated by Balcázar et al. (2007). Also, Wang et al. (2008) showed the bacterial strain Enteroccus faecium treated as probiotic succeeded in improving certain immunological parameters of tilapia. In the present work, no significant correlations were detected between serum IgM and any types of bacterial counts (table 7) except that female fish showed significant negative correlation between serum $\operatorname{IgM}$ and intestinal total bacterial count. The last decade have been demonstrated that many probiotic agents stimulate certain cellular and humoral functions of the immune system and have a positive effect on fish health (Panigrahi et al., 2004, 2005; Balcázar et al., 2007).

\section{CONCLUSION}

Avi-Lution probiotic has good effect on the catfish Clarias lazera not only by reducing the counts of E. coli, Klebsiella spp. and Pseudomonas spp. but also by enhancing the physiological functions and the immunity of the fish.

\section{ACKNOWLEDGEMENT}

The authors wish to thank Prof. Dr. Emad Mokhtar, Prof. of Bacteriology, Animal Health Res. Institute, for useful comments on the manuscript. The first author is highly thankful to Salhia Green Company managers (Dr. Mohammed R. Belassi and Saied R. Belassi) for supplying probiotic.

\section{REFERENCES}

Abd El-Rhman A. M.; Khattab, Y. A. E. and Shalaby, A. M. E. (2009). Micrococcus luteus and Pseudomonas species as probiotics for promoting the growth 
performance and health of Nile tilapia, Oreochromis niloticus. Fish \& Shellfish Immun., 27: 175-180.

Abdel-Tawwab, M.; Abdel-Rahman, A.M. and Ismael, N.E.M. (2008). Evaluation of commercial live bakers' yeast, Saccharomyces cerevisiae as a growth and immunity promoter for Fry Nile tilapia, Oreochromis niloticus challenged in situ with Aeromonas hydrophila.. Aquaculture, 280: 185-189.

Abonorag, M.A.; Fahmy, B.A.G.; Ali, A.T. and Rizkalla, E.H. (2011). Effect of the probiotic Biowish on aquaculture water quality and biochemical profile of the Nile catfish "Clarias lazera”. J. Egypt. Ger. Soc. Zool., 62 A: 137-153.

Agri-King (2000): Avi-Lution ${ }^{\circledR}$ Water Soluble and Avi-Lution ${ }^{\circledR}$ Custom Product Information. Agri-King, Inc., Fulton, Illinois 61252 USA (agriking@worldnet.att.net).

Al-Harbi, A.H. and Uddin, N. (2003). Quantitative and qualitative studies on bacterial flora of hybrid tilapia (Oreochromis niloticus X O. aureus) cultured in earthen pond in Saudia Arabia. Aquacult. Res., 34, 43-48.

Austin, B., and Austin, D.A. (1989). "Microbiological Examination of Fish and Shellfish". Ellis Horwood, Chichester.

Austin, B., Stuckey, L.F., Robertson, P.A.W., Effendi, I., Griffith, D.R.W. (1995): A probiotic strain of Vibrio alginolyticus effective in reducing diseases caused by Aeromonas salmonicida, Vibrio anguillarum and Vibrio ordalii. J. Fish Dis., 18: 93-96.

Balcázar, J.L.; de Blas, I.; Ruiz-Zarzuela, I.; Vendrell, D.; Calvo, A.C.; Márquez, I.; Gironés, O. and Muzquiz, J.L. (2007). Changes in intestinal microbiota and humoral immune response following probiotic administration in brown trout (Salmo trutta). Bri. J. Nutr., 97: 522-527.

Bandyopadhyay, P. and Das Mohapatra, P.K. (2009). Effect of a probiotic bacterium Bacillus circulans PB7 in the formulated diets: on growth, nutritional quality and immunity of Catla catla (Ham.). Fish Physiol. Biochem., 35: 467- 478.

Bartles, H.; Bohmer, M. and Heirli, C. (1972). Serum creatinine determination without protein precipitation. Clin. Chem. Acta, 37: 193-197.

Bengmark, S. (1998): Ecological control of the gastrointestinal tract. The role of probiotic flora. Gut, 42: 2-7.

Beutin, L.; Mtenegro, M.A.; Orskov, I.; Orskov, F.; Prada, J.; Zimmermann, S. and Stephen, R. (1989). Close association of verotoxin (shiga-like toxin) production with enterohemolysin production in strains of Escherichia coli. J. Clin. Microbiol., 27 (11): 2559-2564.

Birkbeck, T.H. and Ringø, E. (2005). Pathogenesis and the gastrointestinal tract of growing fish. In "Microbial Ecology in Growing Animals", pp. 208-234 [W Holzapfel \& P Naughton, editors]. Biology in Growing Animals Series [SG Pierzynowski \& R Zabielski, editors]. Edinburgh: Elsevier.

Bondad-Reantaso, M.G.; Subasinghe, R.P.; Arthur, J.R.; Ogawa, K.; Chinabut, S.; Adlard, R.; Tan, Z. and Shariff, M. (2005). Disease and health management in Asian aquaculture.Vet. Parasitol., 132: 249-272.

Brook, I.; Rogers, J.; Rollins, D.M.; Coolbaugh, J.C. and Walker, R.I. (1985). Pathogenicity of Aeromonas. J. Infect., 19 (1): 32-37.

Burr, G.; Gatlin, D. III and Ricke, S. (2005). Microbial ecology of the gastrointestinal tract of fish and the potential applications of prebiotics and probiotics in finfish aquaculture. J. World Aqua. Soc., 36 (4): 425-436.

Burtis, C.A.; Edward, R. and Ashwood, M.D. (1999). "Tietz Textbook of Clinical Chemistry". $3^{\text {rd }}$ ed., Am. Assn. for Clin. Chem. 
Cahill, M.M. (1990). Bacterial flora of fishes: A Review. Microb. Ecol. 19: 21-41.

Carter, G.R. and Cole, J.R. (1990). "Diagnostic Procedures in Veterinary Bacteriology and Mycology". $5^{\text {th }}$ ed., Acad. press Inc., New York, Boston, Tokyo, Toronto.

Cohen, P. P. (1976). Evolutationary and comparative aspects of urea biosynthesis. In: "The urea cycle". S. Grisolia, R. Baguena, F. Mayor eds., John Wiley \& Sons, New York, 21-28.

Danish Standards Association (2002). Water Quality - Enumeration of Culturable Micro-organisms - Colony Count by Inoculation in a Nutrient Agar Culture Medium. (Danish Standard No.DS/EN ISO 6222/Till.1:2002). Danish Standards Association, Charlottenlund, Denmark.

Denev, S.A. (2008). "Ecological Alternatives of Antibiotic Growth Promoters in the Animal Husbandry and Aquaculture”. D.Sc. Thesis, Dept. Biochem. Microbiol., Trakia Univ., Stara Zagora, Bulgaria, pp 294.

Denev, S.A.; Staykov, Y.; Moutafchieva, R. and Beev, G. (2009). Microbial ecology of the gastrointestinal tract of fish and the potential application of probiotics and prebiotics in finfish aquaculture. Int Aquat Res, 1: 1-29.

Doumas, B.T.; Watson, W.A. and Biggs, H.C. (1971). Albumin standards and the measurement of serum albumin with bromocresol green. Clin. Chem. Acta, 31: $87-96$.

Emikpe, B.O.; Adebisi, T. and Adedji, O.B. (2011). Bacteria load on the skin and stomach of Clarias gariepinus and Oreochromis niloticus from Ibadan, South west Nigeria.: Public health implications. J. Microbiol. Biotech. Res., 1 (1): 5259.

FAO. (2006). "Fisheries Statistics: Aquaculture Production", 88/2. FAO, Rome, Italy, pp. 12.

Fawcett, J.K. and Soctt, J.E. (1960). A rapid and precise method for the determination of urea. J. Clin. Path., 13 (2): 156-159.

Finegold, S.M. and Martin, W.T. (1982). "Diagnostic Microbiology". $6^{\text {th }}$ Ed. The C.V. Mosby Co., USA 241-245.

Gray, S.J.; Stickler, D.J. and Bryant, T.N. (1990). The incidence of virulence factors in mesophilic Aeromonas species from animals and environment. Epidemicl. Infect., 105: 277 -294.

He, S.; Zhou, Z.; Liu, Y.; Shi, P.; Yao, B.; Ringø, E. and Yoon, I. (2009). Effects of dietary Saccharomyces cerevisiae fermentation product (DVAQUA®) on growth performance, intestinal autochthonous bacterial community and nonspecific immunity of hybrid tilapia (Oreochromis niloticus $\$ \times O$. aureus ${ }^{\Uparrow}$ ) cultured in cages. Aquaculture, 294: 99-107.

Hooge, D.M. (2000). New direct-fed microbial, Avi-Lution ${ }^{\circledR}$, successful alternative to bacitracin-MD or virginiamycin for improving weight and FCR in broilers. Feedinfo.com - News, November 15, 2000.

Hoseinifar, S.H.; Mirvaghefi, A.; Merrifield, D.L.; Amiri, B.M.; Yelghi, S. and Bastami, K.D. (2011). The study of some haematological and serum biochemical parameters of juvenile beluga (Huso huso) fed oligofructose. Fish Physiol. Biochem., 37: 91-96.

International Commission on Microbiological Specification for Food 'I.C.M.S.F.' (1978)."Microorganisms in Foods: their Significance and Method of Enumeration". $2^{\text {nd }}$ Ed. Univ. of Toronto. Press, Toronto, London.

International Commission on Microbiological Specification for Food 'I.C.M.S.F.' (1982). "Microorganisms in Food. 1. Salmonella". $2^{\text {nd }}$ Ed. Univ. of Toronto, Toronto Press, Toronto, p. 201. 
Irianto, A. and Austin, B. (2002). Probiotics in aquaculture. J. Fish Dis., 25: 633-642.

Israelsson, O.; Petersson, A.; Bengtén, E.; Wiersma, E.J.; Andersson, J.; Gezelius, G. and Pilström, L. (1991). Immunoglobulin concentration in Atlantic cod, Gadus morhua L., serum and cross-reactivity between anti-cod antibodies and immunoglobulins from other species. J. Fish Biol., 39: 265-278.

Kamgar, M.; Pourgholam, R.; Ghiasi, M. and Ghane, M. (2013). Studies on Bacillus subtilis, as potential probiotics, on the biochemical parameters of rainbow trout, Oncorhynchus mykiss (Walbaum) to challenge infections. Advanced Studies in Biology, 5 (1): 37-50.

Kesarcodi-Watson, A.; Kaspar, H.; Josie Lategan, M. and Gibson, L. (2008). Probiotics in aquaculture: The need, principles and mechanisms of action and screening processes. Aquaculture, 274: 1-14.

Khattab, Y.A.E.; Shalaby, A.M.E.; Sharaf, S.M.; El-Marakby, H.I. and Rizkalla, E.H. (2004). The physiological changes and growth performance of the Nile tilapia Oreochromis niloticus after feeding with Biogen ${ }^{\circledR}$ as growth promoter. Egypt. J. Aquat. Biol. \& Fish., 8 (2): 145-158.

Khattab, Y.A.E.; Shalaby, A.M.E. and Abdel-Rahman, A. (2007). Use of probiotic bacteria as growth promoters, anti-bacterial and their effects on physiological parameters of Oreochromis niloticus. Proc. $7^{\text {th }}$ Int. Symp. on Tilapia Aquacul., 156-170.

Kirov, S.M.; Wellock, R.C.; Goldssmid, J.M. and Vangalen, A.D. (1986). Virulence charcteristics of Aeromonas Spp. in relation to source and biotype. J. Clin. Microbiol., 24 (5): 827 -834.

Klesius, P.H. (1990). Effect of size and temperature on the quantity of immunoglobulin in Channel catfish, Ictalurus punctatus. Vet. Immunol. Immunopathol., 24: 187-195.

Konitzer, K. and Voigt, S. (1963). Directbestimmung yon Ammonium in Blut- und Gewebeextracten mit Phenol-Hypochloridreaktion. Clin. Chem. Acta, 8: 5-11.

Kumar, R.; Mukherjee, S.C.; Prasad, K.P. and Pal, A.K. (2006): Evaluation of Bacillus subtilis as a probiotic to Indian major carp Labeo rohita (Ham.). Aquacul. Res., 37 (12): 1215-1221.

Magnadóttir, B. (1998). Comparison of immunoglobulin (IgM) from four fish species. Icel. Agr. Sci., 12: 47-59.

Magnadóttir, B.; Guðmundsdóttir, S. and Guðmundsdóttir, B.K. (1995). Study of the humoral response of Atlantic salmon (Salmo salar L.), naturally infected with Aeromonas salmonicida ssp. achromogenes. Vet. Immunol. Immunopathol., 49: 127-142.

Magnadóttir, B.; Jónsdóttir, H.; Helgason, S.; Björnsson, B.; Jørgensen, T.Ø. and Pilström, L. (1999a). Humoral immune parameters of Atlantic cod (Gadus morhua L.). I: The effects environmental temperature. Comp. Biochem. Physiol., 122B: 173-180.

Magnadóttir, B.; Jónsdóttir, H.; Helgason, S.; Björnsson, B.; Jørgensen, T.Ø. and Pilström, L. (1999b). Humoral immune parameters in Atlantic cod (Gadus morhua L.). II: The effects of size and gender under different environmental conditions. Comp. Biochem. Physiol., 122B: 181-188.

Mahmoud, H.K. (2012). "Effect of Some Managerial and Environmental Factors on Fish Performance". Ph.D. Thesis (Animal Production), Fac. Agriculture, Zagazig Univ. 
Matyar, F.; Di-Ncer, S.; Kaya, A. and Colak, O. (2004). Prevalence and resistance to antibiotics in gram negative bacteria isolated from retail in fish in Turkey. Annales of Microbiology, 54 (2): 151-160.

Mesalhy, A.S.M.; Yousef, A.G.A.; Ghareeb, A.A.A. and Mohamed, M.F. (2008). Studies on Bacillus subtilis and Lactobacillus acidophilus, as potential probiotics, on the immune response and resistance of Tilapia nilotica (Oreochromis niloticus) to challenge infections. Fish Shellfish Immunol., 25: 128-136.

Nayak, A.K.; Das, B.K.; Kohli, M.P.S. and Mukherjee, S.C. (2004). The immunosuppresive effect of $\alpha$-permethrin on Indian major carp, rohu (Labeo rohita). Fish and Shellfish Immunol., 16: 41-50.

Nikoskelainen, S.; Ouwehand, A.C.; Bylund, G.; Salminen, S. and Lilius, E-M. (2003). Immune enhancement in rainbow trout (Oncorhynchus mykiss) by potential probiotic bacteria (Lactobacillus rhamnosus). Fish Shellfish Immunol., 15: 443-452.

Olesen, N.J. and Vestergård-Jørgensen, P.E. (1986). Quantification of serum immunoglobulin in rainbow trout Salmo gairdneri under various environmental conditions. Diseases of Aquatic Organisms, 1: 183-189.

Palikova, M.; Navratil, S.; Krejcf, R.; Sterba, F.; Tichy, F. and Kubala, L. (2004). Outcomes of repeated exposure of carp (Cyprinus carpio L.) to Cyanobacteria extract. Acta, Vet. Brno., 73: 259-265.

Palumbo, S.A.; Bencivengo, M.M.; Delcorral, F.; William, A.C. and Buchaman, R.L. (1989). Characterization of the Aeromonas hydrophila isolated from retail foods of animal origin. J. Clin. Microbiol., 27 (5): 854-859.

Panigrahi, A.; Kiron, V.; Kobayashi, T.; Puangkaew, J.; Satoh, S. and Sugita, H. (2004). Immune responses in rainbow trout Oncorhynchus mykiss induced by a potential probiotic bacteria Lactobacillus rhamnosus JCM 1136. Vet. Immunol. Immunopathol., 102: 379-388.

Panigrahi, A.; Kiron, V.; Puangkaew, J.; Kobayashi, T.; Satoh, S. and Sugita, H. (2005). The viability of probiotic bacteria as a factor influencing the immune response in rainbow trout Oncorhynchus mykiss. Aquaculture, 243: 241-254.

Panigrahi, A.; Kiron, V.; Satoh, S. and Watanabe, T. (2010). Probiotic bacteria Lactobacillus rhamnosus influences the blood profile in rainbow trout Oncorhynchus mykiss (Walbaum). Fish Physiol. Biochem., 36: 969-977.

Peter, F.; Stephen, D.; Weagant, M. and Grant, A. (1998). "Enumeration of Escherichia coli and the coliform". Bacteriological Analytical Manual 'BAM', $8^{\text {th }}$ Ed., chapter4.

Post, G. (1987). "Textbook of Fish Health". Revised and Expanded Edition. T.F.H. Publications, Inc.

Racicot, J.G.; Gaudet, M. and Leray, C. (1975). Blood and liver enzymes in rainbow trout (Salmo gairdneri) with emphasis on their diagnostic use: study of $\mathrm{CCl}_{4}$ toxicity and a case of Aeromonas infection. J. Fish Biol., 7: 825-835.

Reitman, S. and Frankel, S. (1957). Colorimetric determination of glutamic transaminase. Am. J. Clini. Pathol., 28: 56.

Ringø, E.; Olsen, R.E.; Mayhew, T.M. and Myklebust, R. (2003). Electron microscopy of the intestinal microflora of fish. Aquaculture, 227: 395-415.

Robins-Browne, R.M.; Yam, W.C.; O’Gorman, L.E. and Bettelheim, K.A. (1993). Examination of archetypal strains of enteropathogenic Esherichia coli for properties associated with bacterial virulence. J. Med. Microbiol., 38 (3): 222-226. 
Rosalki, S.B.; Foo, A.Y.; Burlina, A.; Prellwitz, W.; Stieber, P.; Neumeier, D.; Klein, G., Poppe, W.A. and Bodenmuller, H. (1993). Multicenter evaluation of IsoALP test kit for measurement of bone alkaline phosphatase activity in serum and plasma. Clin. Chem., 39 (4): 648-652.

Saha, N. and Ratha, B.K. (1989). Comparative study of ureogenesis in freshwater airbreathing teleost. J. Exp. Zool., 252: 1-8.

Saha, N.; Chakravorty, J. and Ratha, B.K. (1988). Diurnal variation in renal and extrarenal excretion of ammonia- $\mathrm{N}$ and urea-N in freshwater air-breathing teleost, Heteropneustes fossilis (Bloch). Proc. Indian Acad. Sci., 97: 529-537.

Sahu, M.K.; Swarnakumar, N.S.; Sivakumar, K.; Thangaradjou, T. and Kannan, L. (2008). Probiotics in aquaculture: importance and future perspectives. Indian J. Microbiol., 48: 299-308.

Sanaa, O. and Yagoub (2009). Isolation of Enterobacteriaceae and Pseudomonas spp. from raw fish sold in fish market in Khartoum state. J. Bact. Res., 1 (7): 85-88.

Shunpei, I.; Tadashi, I.; Suguru, O.; Miyo, N.; Reiji, T. and Hiroto, M. (2009). Colonization and probiotic effects of lactic acid bacteria in the gut of the abalone Haliotis gigantean. Fish Sci., 75: 1285-1293.

Soondeuk, L. and Yeonhee, L. (1995). Identification of intestinal microflora in rainbow trout. J. Microbiol., 33 (4): 273-277.

Statner, B. and George, W.L. (1987). Congo red uptake by motile Aeromonas species. J. Clin. Microbiol., 25: 876-878.

Subasinghe, R.; Soto, D. and Jia, J. (2009). Global aquaculture and its role in sustainable development. Reviews in Aquacul., 1: 2-9.

Tovar, R.D.; Zambonino, I.J.; Cahu, C.; Gatesoupe, F.J. and Vazquez-Juarez, R. (2004). Influence of dietary live yeast on European sea bass (Dicentrarchus labrax) larval development. Aquaculture, 234: 415-427.

Tukmechi, A.; Morshedi, A. and Delirezh, N. (2007). Changes in intestinal microflora and humoral immune response following probiotic administration in rainbow trout (Oncorhynchus mykiss). J. Animal Vet. Adv., 6 (10): 1183-1189.

Vasudevan, D.M. and Sreekumari, S. (1998). "Text Book of Biochemistry for Medical Students", $3^{\text {rd }}$ edn. Jaypee Publishers, New Delhi, India.

Verschuere, L.; Rombaut, G.; Sorgeloos, P. and Verstraetr, W. (2000). Probiotic bacteria as biological control agents in aquaculture. Microbiol. Mol. Biol. Rev., 64 (4): 655-671.

Wang, Y.B.; Tian, Z.O.; Yao, J.T. and Li, W. (2008). Effect of probiotics, Enteroccus faecium, on tilapia (Oreochromis niloticus) growth performance and immune response. Aquaculture, 277: 203-207.

Wedemeyer, G.A. and Mcleay, D.J. (1981). Methods for determining the tolerance of fishes to environmental stressors. In: Pickering AD (ed.) "Stress and Fish". Academic Press, London, pp 246-275.

Wilson, R.P. (1973). Nitrogen metabolism in channel catfish, Ictalurus punctatus. II. Evidence for an apparent complete ornithine-urea cycle. Comp. Biochem. Physiol., 46: 625-634. 


\section{ARABIC SUMMARY}

تغيرات المحتوى البكتيرى للأمعاء والمؤشرات البيوكيميائية لمصل أسماك قرموط النيل المغذاة بالبروبيوتيك.

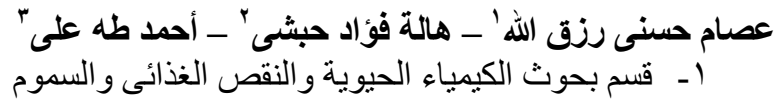

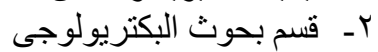

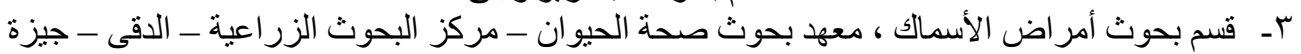

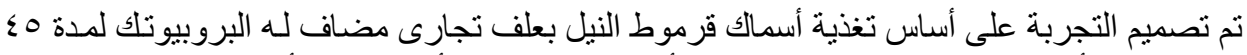

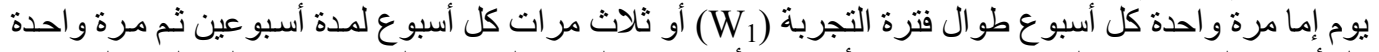

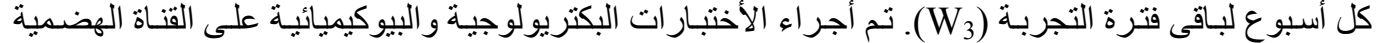

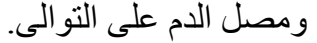

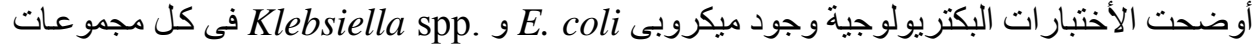

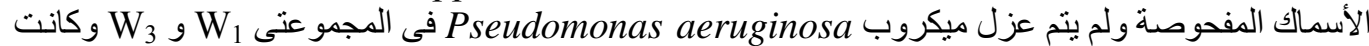

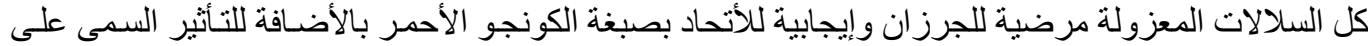

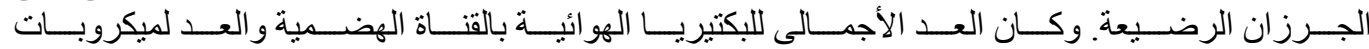
Enterobactereacae

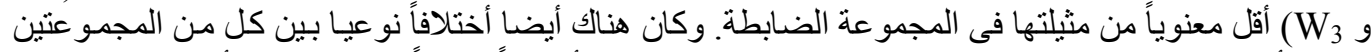

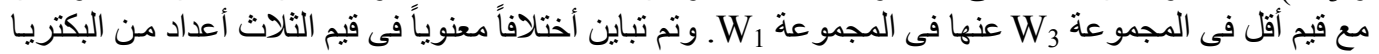

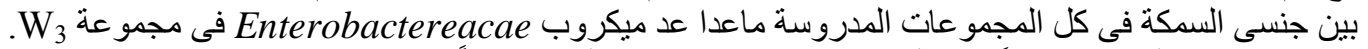

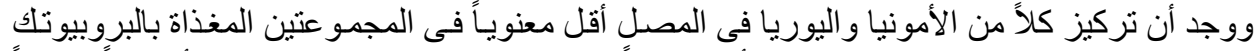

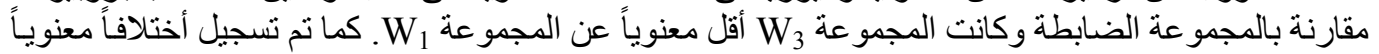

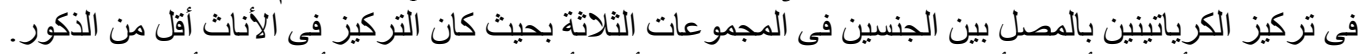

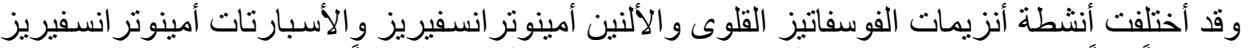

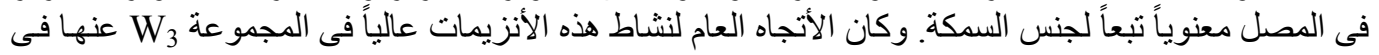

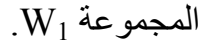

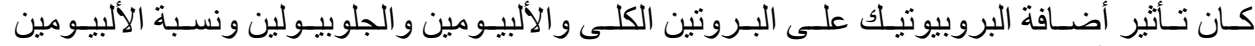

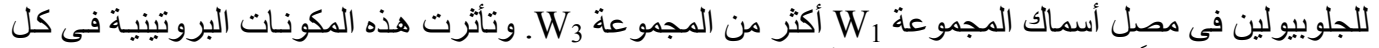

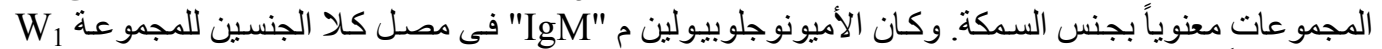

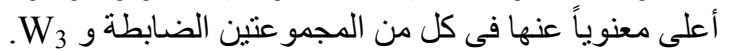

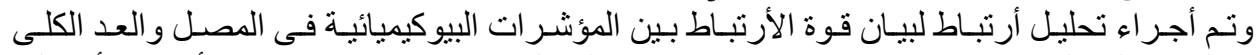

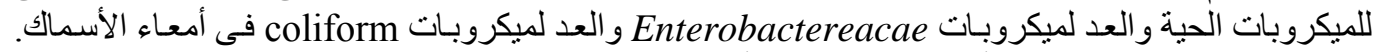

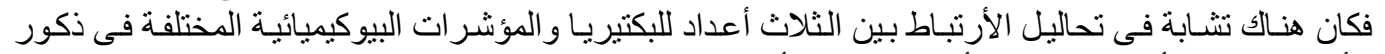

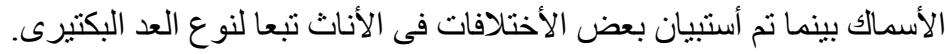

